\title{
STRUCTURAL TRANSFORMATION IN WEST KALIMANTAN TOWARDS ASEAN ECONOMIC COMMUNITY 2015
}

\author{
Memet Agustiar \\ Department of Economics, University of Tanjungpura \\ e-mail: latifatulsyukron@gmail.com
}

\begin{abstract}
This paper explores the patterns of economic transformation in West Kalimantan during the last 40 years, calculates productivity, and examines the impact of agriculture sector decline on nonagricultural sector performance. It finds that economic transformation has taken place in West Kalimantanand that the $\mathrm{p}$ roductivity of agricultural sector remains low. It also finds that the decline in agriculture sector increases the output of trade and manufacture sectors. The emergence of premature shift in the transformation process can be identified by the analysis. The results suggest initiating an outward-looking policy through an active participation within the sub-regional cooperation in ASEAN.
\end{abstract}

Keywords: Economic transformation, productivity, ASEAN

JEL classificationn umbers: $\mathrm{O} 13, \mathrm{O} 14$

DOI: $\underline{\text { http://dx.doi.org/10.20885/ejem.vol5.iss1.art6 }}$

\begin{abstract}
Abstrak
Makalah ini mengeksplorasi pola transformasi ekonomi di Kalimantan Barat selama 40 tahun terakhir, menghitung produktivitas sektoral, serta mengkaji dampak penurunan sektor pertanian terhadap kinerja sektor non-pertanian. Penelitian ini menemukan bahwa transformasi ekonomi telah terjadi di Kalimantan Barat, dan bahwa produktivitas sektor pertanian tetap rendah. Penelitian ini juga menemukan bahwa penurunan pangsa sektor pertanian mendorong kenaikan output di sektor perdagangan dan manufaktur. Munculnya pergeseran prematur dalam proses transformasi juga teridentifikasi oleh analisis yang dilakukan. Penemuan ini menyarankan perlunya kebijakan yang berorientasi keluar untuk melakukan partisipasi aktif dalam kerjasama sub-regional di ASEAN.
\end{abstract}

Kata Kunci:Transformasi ekonomi, produktivitas, ASEAN

JEL classificationn umbers: $\mathrm{O} 13, \mathrm{O} 14$

\section{INTRODUCTION}

Economic growth is a temporary representation of the economy and it is less able to inform the long run economic performance. The experience of West Kalimantan with a rate of growth above 12 per cent during the period 1986-1988 was associated with extreme of poverty and unemployment (Agustiar, 2013).

The experts of economic development emphasize the importance of longterm changes in the economy through stra tural changes. Structural change is a process of change in economic sectors from the traditional low-productivity sector to modern high-productivity sector. Briones and Felipe (2013) investigate the Agriculture and Structural Transformation in Developing Asia. Buera and Kaaboski (2009) try to find out whether theories of structural change fit the data.

There are two starting processes of economic transformation experienced by various countries. First, the transformation starts from the manufacturing industry. In this case, the accumulation of capital, tech- 
nology implementation, and institutional reforms focused on strengthening the manufacturing industry. Other sectors will automatically experience the positive effects of the manufacturing sector. Second, it starts from the agricultural sector, then the transformation of agriculture that will provide acceleration to the manufacturing and service sectors. Economic transformation associated with increase in share of the manufacturing industry urbanization and technological innovation.

Historical development of West Kalimantan's economy has been identified in previous studies. The early study of Jackson (1970) and conducted a review of the economy of West Kalimantan concerning to structural dynamics, cultural and natural resources.

The first gold rushers came from China (Hoakiau tribe from Fukien and Hakka tribe from the Kwantung) in $18^{\text {th }}$ century (Jackson, 1970). They operated in in Sambas, Montrado and Bengkayang and continue to remote areas in Sepauk, Sungai Ayak, Sintang, and Nanga Semangut until the end of $19^{\text {th }}$ century. The second round of gold rusher reappears in the 1990's in the form of local small-scale mining.
The timber boom is one of significant role in West Kalimantan economy during 1971-1975. Timber firm grew from 23 firms in 1970s to more than 100 in the mid 1990s. It came to slow in the late 1980s. Setiadi et al. (2006) reported that 7853 employees resigned during the period 19872000, and it continued reaching 12 thousand by the end of 2006. Weaker growth in timber firms is due to the raw material crisis.

Rubber became the main job source of the population almost in the entire region, while coconut palm planted in coastal areas from $18^{\text {th }}$ century to now. Province Office of West Kalimantan Plantation (2011) reported that there were about 588 thousand hectares of rubber plantation employed 314 thousand farmers, supported by 20 rubber processing companies. Entering the 1980's an important shift in the agricultural sector is characterized by the influx of investors in oil palm plantation initiated by PT Nusantara (PTPN). Until the year 2011, oil palm plantations spread across mostly areas of West Kalimantan reaches 880 thousand hectare and absorb 93 thousand of family farmers, and managed by 226 large plantation companies, 26 of which are foreign companies (Province Office of West Kalimantan Plantation, 2011).

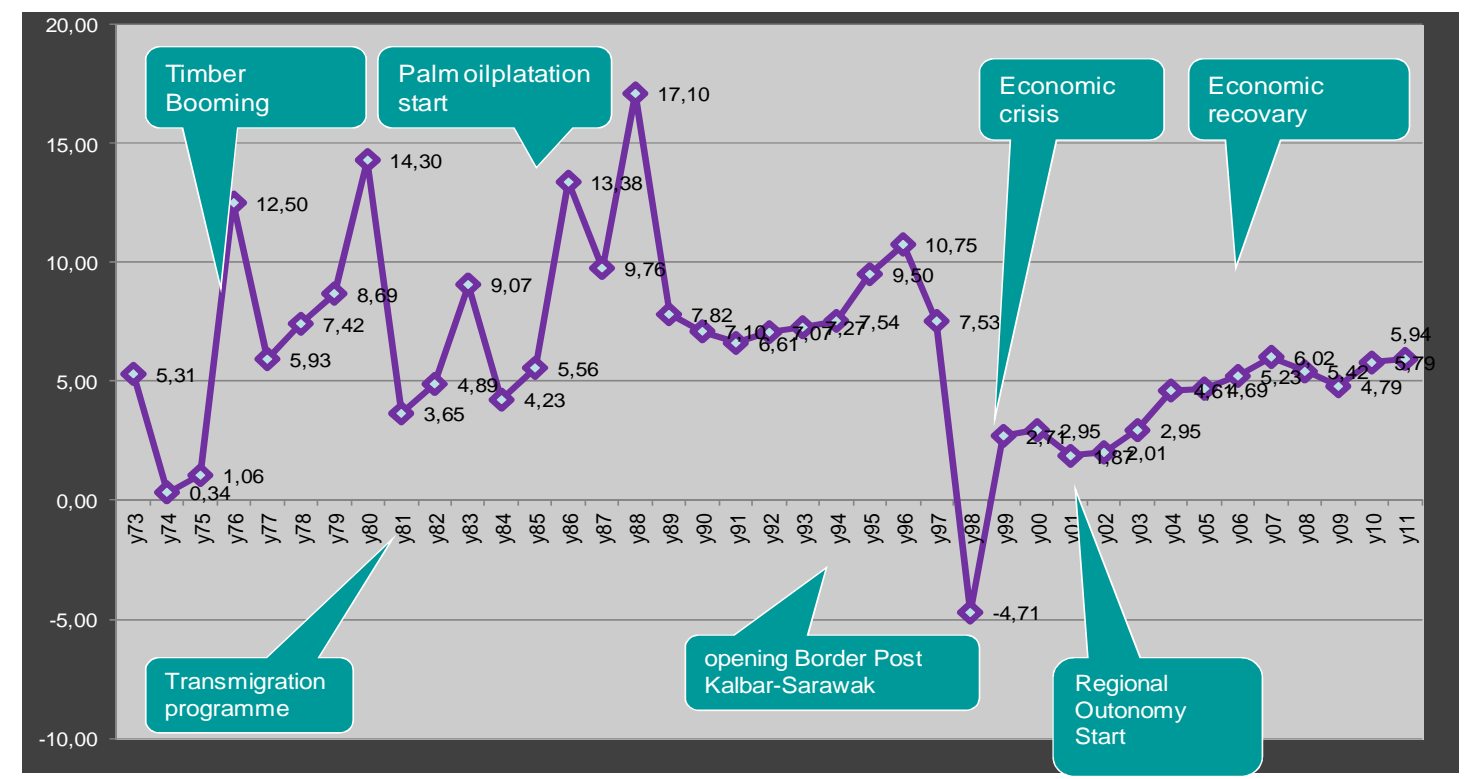

Source: Central Bureau of Statistics, 1972-2011.

Figure 1: Pattern of Economic Growth in West Kalimantan 1973-2011 
When the economic crisis hit Southeast Asia in 1997, the economic growth decreased to -4.71 per cent. Surprisingly, agricultural sector has a less impact. Fariastuti (1999) reported that the prices of some agricultural commodities have increased during the economic crisis. Price of rubber rise from Rp 800 to $\mathrm{Rp} \mathrm{3,000} \mathrm{per} \mathrm{kg}$ ) and pepper up from Rp 5000 to $\mathrm{Rp} \mathrm{65,000} \mathrm{per} \mathrm{kg}$. On the contrary, the 2008s financial crisis decreased the price some of major agricultural commodities. Agustiar (2012) reported that the price of rubber fell from Rp 17,000 per kg to Rp 5,700 per kg (decreases about 66 per cent), and Crude Palm Oil prices dropped from $\mathrm{Rp} \mathrm{5,655} \mathrm{per} \mathrm{kg}$ to $\mathrm{Rp} 3,581$ per $\mathrm{kg}$. After the 1997 crisis, the economy of West Kalimantan was controlled by two important subsectors, namely retail trade and construction (Agustiar, 2013). The construction of shopping canters, mobile phones business, motor vehicles, restaurants, and automotive are key drivers during the post crisis.

According to Hill et al. (2006), a structural change in Indonesia was considered too fast. Mitsuhiro (2005) conducted a study on the structural changes in Indonesia using the Input-Output model. He found that the industrialization push up production, expanding export orientation and reduce dependence on imports. Majid (2012) analyzed the contribution of capital input and labour to the sectoral performances using stochastic frontier production function models. The result shows that the role of capital and labour at 0:34 and 0:20.

The past figure provides a detailed understanding of how the economic progress of the West Kalimantan develops from time to time. An important academic question would be whether there has been significant shift in the economic structure of West Kalimantan during the past 40 years. This paper aims to describe the stra tural changes in the economy during the 40 years of West Kalimantan, calculate the total sectoral productivity by comparing the ratio between output and employment in selected sectors, and to test the impact of changes in the agricultural sector to the non-agricultural sector. At the last section, this paper will elaborate any relevant policy agenda for West Kalimantan.

\section{METHODS}

Studies on structural changes generally use dynamic data, in the form of time-series which describes the movement of share of each sector in the economy. There is also the use of input-output model which uses static data. Other study tried to account for sectoral productivity by comparing how much the role of inputs in producing output (Freeman, 2008). Such studies usually compare whether there was an increase in the productivity of the agricultural sector in line with the drop in share of the agricultural sector.

This study used data on the publication by the Indonesian Central Bureau of Statistics. Sectoral GDP data starting from 1976, while the sectoral data on the number of workers beginning in 1971.

Model 1: Calculating the sectoral output share:

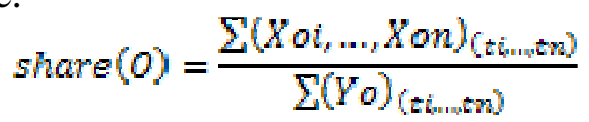

where, Share(0) is sectoral output share, Xoi. .Xon is number of sectoral GDP in sector $X i . . X n$, and $\Sigma Y o$ is the amount of total sectoral GDP and $(t i, \ldots, t n)$ represent year 1 to $n$.

Model 2: Counting the sectoral labour share:

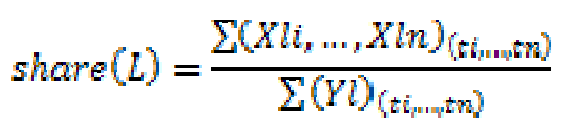

where, Share $(L)$ is sectoral labour share, and $X l i \ldots X \ln$ is the amount of labour in sector $X i \ldots X n$ and $\Sigma Y l$ is a total work force of all sectors, $(t i, \ldots, t n)$ represent year 1 to $n$.

Model 3: Calculate the labour productivity in the four sectors (agriculture, manufactur- 
ing, trade and services). The model used to calculate the sectoral productivity is to compare the share input with the output share, written by:

$p o l=\frac{\sum(X o i, \ldots, X o n)_{(t h, \ldots, t n)}}{\sum(\mathrm{Yo})_{(t, i, \ldots, t n)}} / \frac{\sum(X l i, \ldots, X l n)_{(t i \ldots, t n)}}{\sum(\mathrm{Yl})_{\left(t i_{n, \ldots, t n)}\right.}}$

Where, pol is productivity rate of sectors $=$ output/input, Xoi,...,Xon = sectoral output, $X l i, \ldots, X l n=$ sectoral employment, $Y o=$ total output, $Y l=$ total employment, $(t i, \ldots, t n)$ represents year 1 to $n$.

Model 4: Test the impact of the decline of the agricultural sector to non-agricultural sectors. The first test will examine the impact of a decline in share of agricultural sector to the manufacturing sector, and then test the impact of the decline in the share of agricultural sector to the trade sector as well. This test uses regression models of ordinary least squares. Both simple regression model share modified as the first test of autocorrelation found in the DW test. Modifications are done by making a lag on the dependent variable, and then put into the model, as follows:

$$
\begin{aligned}
& \text { mfs }=\beta(1)+\beta(2) \text { agri }+\beta(3) \text { mfs }(-1) \\
& \text { trade }=\beta(1)+\beta(2) \text { agri }+\beta(3) \operatorname{trade}(-1)
\end{aligned}
$$

where $m f s$ is manufacture $t$ rade is trade sector , and agri is agriculture.

\section{RESULTS}

\section{Patterns of Transformation in West Kalimantan}

Figure 2 and Figure 3 presents the calculation of the sectoral share. There are some findings that can be concluded from the economic transformation of West Kaliman$\tan$ in the past 40 years.

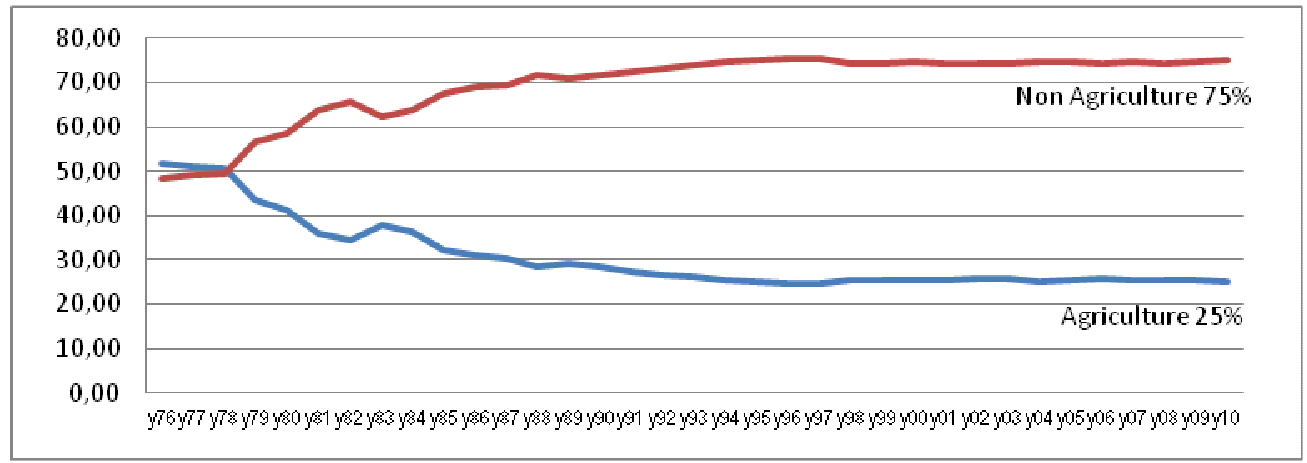

Source: Central Bureau of Statistics, West Kalimantan,1971-2011

Figure 2: Transformation in Agriculture and Non-Agriculture during 1976-2010 (Output)

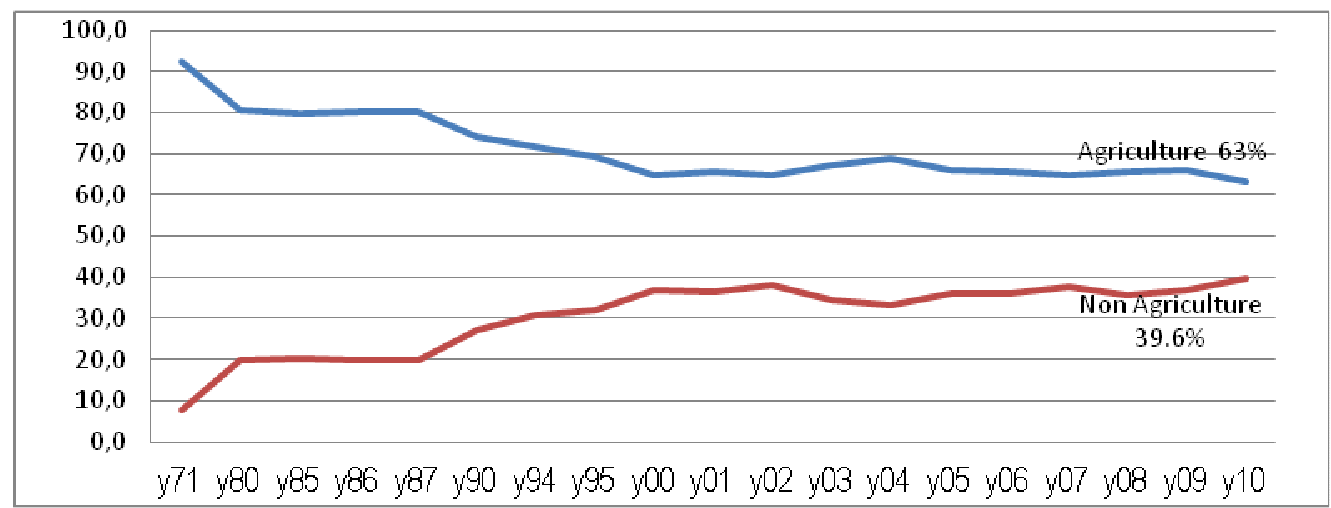

Source: Central Bureau of Statistics, West Kalimantan,1971-2011

Figure 3: Transformation in Agriculture and Non-Agriculture during 1971-2010 (Employment) 
There was a significant difference between the sectoral transformation of output and employment criteria. Sectoral transformation has been clearly identified in terms of output, while in terms of employment it has not clearly been existed. Sectoral transformation of the output has been happening since 35 years ago. Rate of decline in the share of agriculture droped from 50 per cent in 1976 to 25 percent in 2010.

West Kalimantan economic structure has shifted significantly over the last three decades. Agricultural dominance resisted until the late 1980s. Then the trade sector has been replacing the dominance of the agricultural sector until now. Trade sector continues to be at its highest share to the value of over 30 per cent by the end of 2010 .

Since 1994, the share of the agricultural sector has been exceeded by the manufacturing industry. The declining share of the agricultural sector is associated with the lower productivity of this sector. Although the amount of agricultural labour is more, but the productivity of output per capita is much lower than other sectors.

\section{Premature Shift}

Does premature shift really exist in the transformation of West Kalimantan? By looking at the changes pattern over time, there is an indication of premature shift. Theoritically, transformation should shift initially from agriculture to manufacturing, and then continue entring into the service economy. Dasgupta and Singh (2006) describe a premature change as a phenomenon in which developing economies are characterized by the dominance of the service sector to the other sectors.In this study, shifting onagricultural sector is associated to trade sector. This is a symptom of premature shift which means that there is a refraction from agriculture to trade sector. Trade has become a dominant sector in the economy until now.

The question is whether the trade sector constitute the modern sector? By studying the existed data, it turns out that the charge that trade sector is characterized by small and informal traders (such as grocery merchants, street vendors, clothing vendors, and others). This is not really the nature of modernization, it is like a quasishif. Even if there is a leap from agricu 1ture to trade, that leap yet reveal the true characteristics of a leap from the traditional sector to the modern sector.

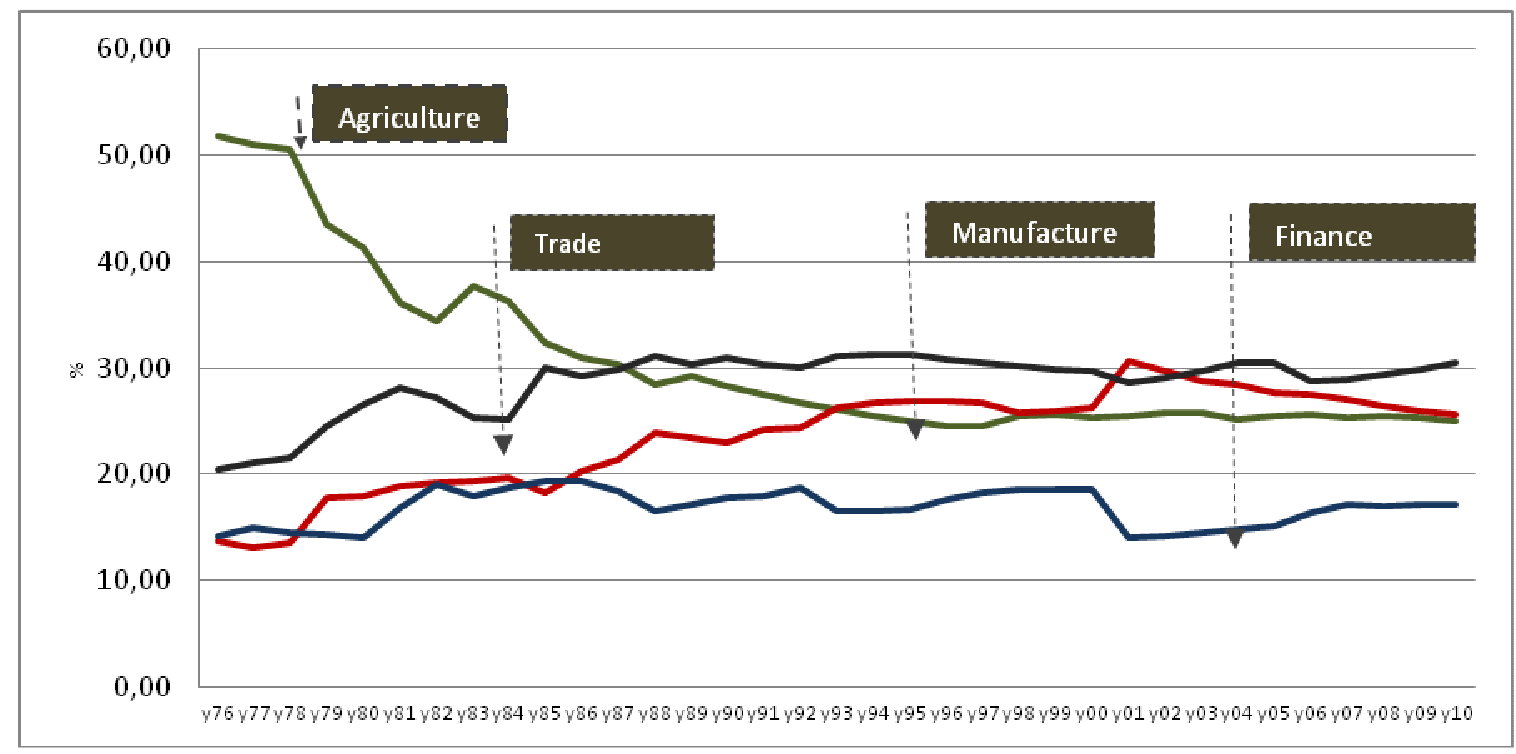

Source: Plotting from Central Bureau of Statistics, West Kalimantan, 1971-2011

Figure 4: Sectoral Transformation in West Kalimantan 1976-2010 (Output Data) 


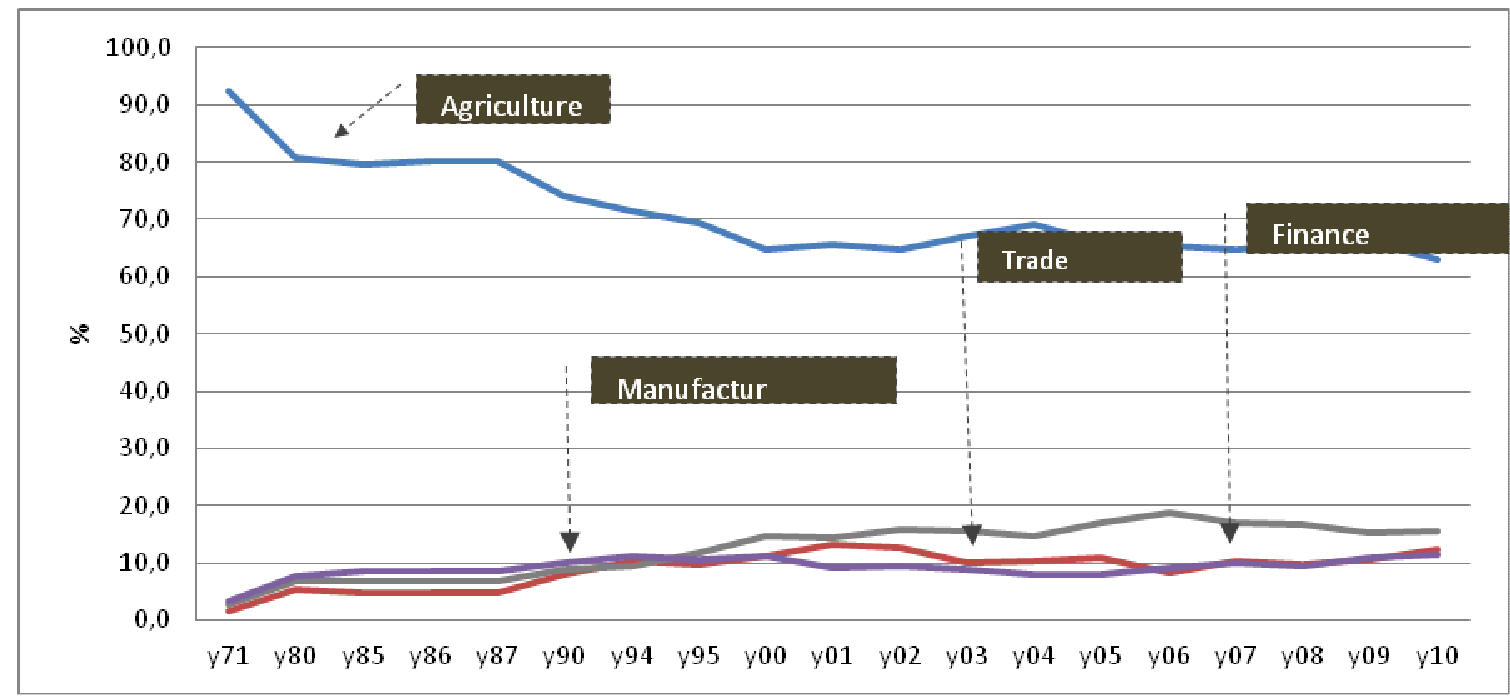

Source: Plotting Indonesia Central Bureau of Statistics, West Kalimantan,1971-2011

Figure 5: Sectoral Transformation in West Kalimantan 1971-2010 (Employment Data)
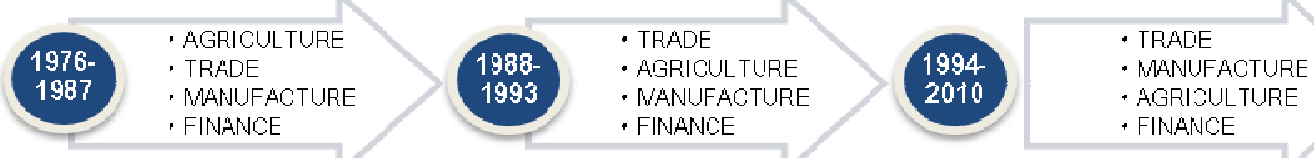

Source: Reviewing from Indonesia Central Bureau of Statistics, West Kalimantan, 1971-2011

Figure 6: The Phase of Sectoral Shift in West Kalimantan

\section{Manufacturing Trend}

An interesting question to be answered is that why the share of manufacturing industry can continue to survive despite some evidence which show a decline in most of the timber companies. There are several possible reasons that could answer it. First, the remaining timber companies can operate by importing raw materials from other provinces. Second, a number of timber companies switch investments into oil palm plantations. On the new land concessions for oil palm plantations, wood obtained from initial land clearing process is another source of wood supply which make local timber companies may survive. Third, timber companies tend to sell the second quality woods for anticipating large demand from urban housing and construction projects.

There is a significant difference between the transformation from the perspective of employment and output. Share of workers in the agricultural sector is still relatively high or as high as 60 per cent in 2010. Conversely share in agricultural output has fallen far reached 25 per cent in 2010. There are several reasons why the contribution of labour in the agricultural sector is still high while output continues to decline. First, oil palm plantations starting from 1980s push the demand of workforce located in rural area. Second, the regular transmigration program from Java will increase the number of workers in the agricultural sector, because they generally work as farmers.

\section{Sectoral Productivity}

The agricultural sector has the lowest level of productivity, which is only an average of 0.4 . It means that a worker in the agricultural sector is only capable of producing an average output of only almost a half (0.4). In the trade and manufacturing sector, a worker is able to produce an average output of 2.5. In the financial and service sectors, labour productivity was recorded at 1.5 times. 
Table1: Sectoral Productivity in West Kalimantan 1980-2010 (Output/Employment)

\begin{tabular}{lccccc}
\hline Sectors & 1980 & 1990 & 2000 & 2010 & Average \\
\hline Trade & 3.9 & 2.6 & 2.0 & 1.9 & 2.6 \\
Manufacture & 3.4 & 2.3 & 2.4 & 2.1 & 2.5 \\
Finance & 1.8 & 1.7 & 1.7 & 1.5 & 1.7 \\
Agriculture & 0.5 & 0.4 & 0.4 & 0.4 & 0.4 \\
Average & 2.4 & 1.8 & 1.6 & 1.5 & \\
\hline
\end{tabular}

Note: Calculated from Indonesia Central Bureau of Statistics, West Kalimantan, 1983-2011.

Average sectoral productivity levels decreased from 2.4 in 1980 to 1.5 in 2010. One indication shows that a growing number of workers entering the labour market, and they are willing to accept lower wages, potentially creating a lower productivity.

\section{Impact of Transforming Agriculture to Manufacturing and Trade Sector}

This session will examine the influence of the transformation in the agricultural sector to the manufacture and trade. The test results revealed that there is a strong relationship between the transformation of agriculture and the development of trade and manufacturing sector. Hypothesis regarding the negative correlation of the agricultural sector with both sectors was clearly identified, with the level of correlation coefficient above 85 per cent.

The next question is how strong an impact the agricultural sector to the trade and manufacturing sector. By showing the value of betta $(\beta)$ in each model shows the agricultural sector had a significant impact in boosting trade and manufacturing. Correlation of the agricultural sector to trade slightly stronger than encouraging manufacturing sector. Timmer and Gaaitzen (2008) has shown this pattern occurs in some Asian countries.

\section{Policy toward sub-Regional Cooperation}

ASEAN Economic Community has a goal to make ASEAN as a single market, strengthening the competitiveness and prosperity of the community members (ASEAN Secretary, 2008). With a market size of 600 million people, ASEAN should be able to be a great economic power, and ASEAN is geographically located between two giants of China and India.

Table 2: Statistical Test of the Impact of Agriculture Sector on Manufacture Sector

\begin{tabular}{ll}
\hline Equation 1 & Agriculture impacts on Manufacture \\
& $\boldsymbol{m} \boldsymbol{f} \mathbf{s}=\boldsymbol{\beta}(\mathbf{1})+\boldsymbol{\beta}(\mathbf{2}) * \boldsymbol{a g r i \boldsymbol { \beta }}+\boldsymbol{\beta}) * \boldsymbol{m} \boldsymbol{f} \mathbf{s}(\mathbf{- 1})$ \\
\hline Substitute coefficient & $m f s=13.729468-0.176396$ agri $+0.654929 m f s(-1)$ \\
& $3.165996-2.6114506 .387013$ \\
R-squared & 0.936978 \\
Adjusted $\mathrm{R}^{2}$ & 0.932912 \\
DW & 1.852357
\end{tabular}

Note:Mfs $=$ Manufacture, Trade $=$ Trade sector, Agri $=$ Agriculture

Table 3: Statistical Test of the Impact of Agriculture Sector on Trade Sector

\begin{tabular}{ll}
\hline Equation 2 & $\begin{array}{l}\text { Agriculture impacts on Trade } \\
\text { trade }=\boldsymbol{\beta}(\mathbf{1})+\boldsymbol{\beta}(\mathbf{2}) * \boldsymbol{a g r i}+\boldsymbol{\beta}(\mathbf{3}) * \operatorname{trade}(\mathbf{- 1})\end{array}$ \\
\hline Substitute coefficient & Trade $=26.76036-0.215549$ agri +0.300954 trade $(-1)$ \\
& $4.254795-3.3902681 .923024$ \\
R-squared & 0.862361 \\
Adjusted $\mathrm{R}^{2}$ & 0.853481 \\
DW & 1.341999 \\
\hline
\end{tabular}

Note: Mfs= Manufacture, Trade $=$ Trade sector, Agri $=$ Agriculture 
Entering into ASEAN single market in 2015, West Kalimantan (Indonesia) should play a more intensive, especially in integrating economic policy into neighboringcountries. Regional cooperation forums such as the BIMP-EAGA and social and economic cooperation between Indonesia and Malaysia (MALINDO) is the appropriate forum for coordinating on a regional basis (Furuoka, 2007, Economic Research Institute for ASEAN and East Asia, 2012).

There are several policy instruments that can be done by West Kalimantan in response to regional dynamics, especially in welcoming the ASEAN Economic Community 2015. First, extending the market size to the Pan Borneo (see figure 7). Borneo has an extensive regional market to reach 35 million people stretching from Sarawak and Sabah (Malaysia), Brunei Darussalam, and Mindanao (Philippines). Superior products of West Kalimantan are expected to compete in the region are product of palm oil, rubber, tropical fruits and textiles.
Second, developing the economic zone. One of the major drawbacks of West Kalimantan is that it does not have any industrial estate. Learning from success stories in implementing Asian model by neighbouring countries, particularly in the construction of the industrial zone, West Kalimantan should be able to replicate the steps. For example, some provinces in $\mathrm{Ma}-$ laysia (Sarawak and Sabah) have more than 10 industrial estates. To support this policy, it needs to strengthen some basic infrastra tures such as airports, electricity, water, and roads.

Third, developing the border. West Kalimantan government has opened four border posts crossing Sarawak (Malaysia) which are Entikong, Aruk, Badau and Jagoi Babang. This policy allows opening access to the mobility of people and goods on the regions. There are some policies that need to be suppored cross-border trade such as gate-point operation should be open within 24 hours, removing the quota of goods traded, and permitting the operation of freight vehicles on a large scale.

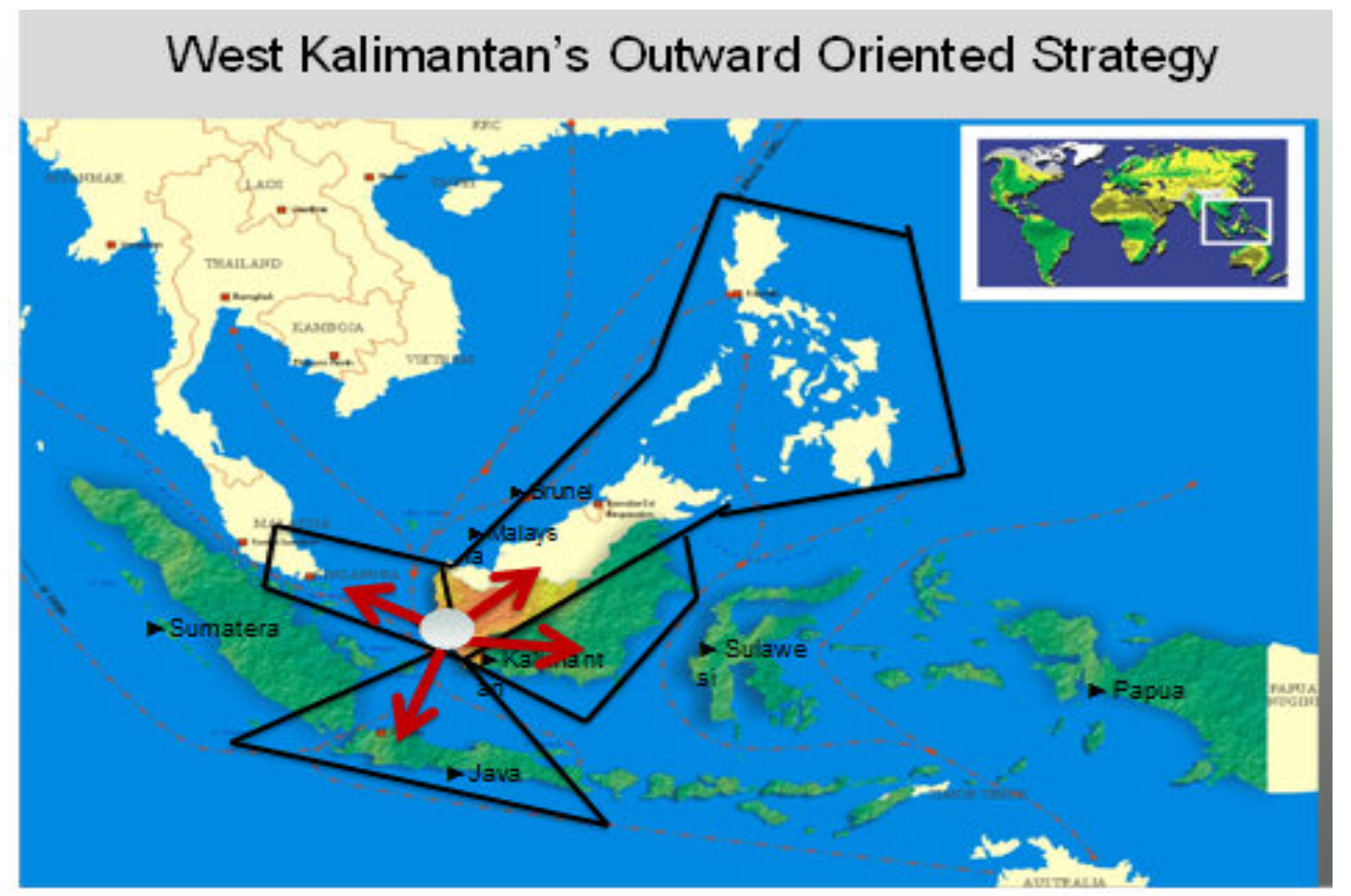

Figure 7: Mapping Potential Partners of West Kalimantan in Regional Context 
Fourth, policies on halal food. BIMP-EAGA region inhabited by the majority of Moslem. Demand for halal food will continue to flourish forward in Asia. Indonesia's role as one of the producers of livestock exposed to take this opportunity. Today, Malaysia has become one of the world's major exporters of halal food, with annual exports of about 11 billion U.S. Dollars (Asian Corner, 2013).

Fifth, professional competency certification of Indonesian foriegn workers. Wave of Indonesian workers in BIMPEAGA region continues to increase. They need policy touch, particularly in strengthening their competencies. The Indonesian government is introducing a professional certification program for Indonesian workers who will go abroad. This policy is expected to encourage the Indonesian labour opportunities in the middle class (especially university graduates) to be able to compete in the regional labour market.

\section{CONCLUSION}

This study found that there was a significant difference in the pattern of sectoral transformation in West Kalimantan from the perspective of output and employment. The important question to be answered is whether sectoral transformation has occurred.The answer is already happening and even more rapidly assessed (viewed from output criteria). However, when viewed from the side of employment, the sectoral transformation has not happened yet.

The gap between output and employment occurs quite serious in agriculture sector. This means that the output transformation in the agricultural sector is not followed by the transformation of employment. By contrast, an increase of output occurs in line with the increase in employment in the trade sector and manufacturing sector. In the agricultural sector, the productivity level was recorded at 0.4 , which means that a worker in the agricultural sector only produces less than half the output. Meanwhile the productivity in the manufacturing sector and the trade reached 2.5 per employee.

Statistical tests on the impact of agricultural transformation towards industrial or trade sectors suggest that the decline in the agricultural sector has a strong correlation to both sectors. The transformation in the agricultural sector is more strongly correlated to the trade sector than to the manufacturing sector.

For the policy concern, this study showed that an outward looking policy has been able to push to the economic transformation. West Kalimantan can continue to expand the policy to a wider scale through various forums such as the BIMP-EAGA cooperation, socio-economic cooperation between Indonesia and Malaysia (SOSEKMALINDO), and the ASEAN Economic Community. Market integration in the axle of Pan-Borneo highway needs to be strengthened. Reducing trade barriers should be formed in order to smooth trade across the borders.Several other policy recommendations that should be considered are policies related to boosting industrial area, developing border development center, developing halal food industries, and strengthening the competence of workforce.

Future research might work on the following issues to strengthen the analysis. First, analyzing the issues using more detailed information on the sub-sector level in order to enrich the analysis. Second, the phenomenon of urbanization in line with the transformation in West Kalimantan has not been revealed in this study. If this is known, it will help explaining how rural-urban linkages in the transformation process.

\section{REFERENCES}

Agustiar, M. (2012), "Business Climate Survey 2010: Grading Regional Competitiveness of West Kalimantan," Indonesian Journal of Business and Management, 3, 316335. 
Agustiar, M. (2013), "West Kalimantan's Preparation Facing to ASEAN Economic Community 2015," Paper presented in Workshop for Exposing of Challenge and Opportunity of ASEAN Economic Community 2015 for Private Sector in West Kalimantan, Organized by the Ministry of Foreign Affair, 12 February 2013, Pontianak.

ASEAN Secretary (2008), ASEAN Economic Community Blue Print, Public Affairs Office of ASEAN, Jakarta.

Asian Corner (2013), "Great Potential of Thai Halals for ASEAN Markets," Available at http://thailand.prd.go.th/view_news.php?id=6745\&a=3, accessed 07June 2013, 4:35 West Indonesia Time.

Briones, R. and J. Felipe (2013), "Agriculture and Structural Transformation in Developing Asia: Review and Outlook," Asian Development Bank Economics Working Paper Series, No. 363, August 2013.

Buera, F., and J. Kaboski, (2009), "Can Traditional Theories of Structural Change Fit the Data?" Journal of the European Economic Association, 7(2-3), 469-477.

Central Bureau of Statistics (2011), West Kalimantan in Number 1971-2011, BPS, Pontianak.

Central Bureau of Statistics (2011), Statistics of Indonesia, BPS, Jakarta.

Central Bureau of Statistics (2003), Directory of Small and Big Company in West Kalimantan, BPS, Pontianak.

Dasgupta, S. and A. Singh (2006), "Manufacturing, Services and Premature DeIndustrialisation in Developing Countries: A Kaldorian Empirical Analysis," Working Paper No. 327 Centre for Business Research, University Of Cambridge.

Economic Research Institute for ASEAN and East Asia (2012), "How to Enhance the Connectivity on BIMP-EAGA?" http://www.eria.org/about_eria/contactus.html, Accessed on 12 September 2013, 08:30 West Indonesia Time.

Fariastuti (1999), "West Kalimantan Economy during the Crisis," Centre for Policy and Implementation Studies, Jakarta.

Freeman, R. (2008), Labour Productivity Indicator, OECD Statistics Directorate Division of Structural Economic Statistics.

Furuoka, F. (2007), "Econometric Analysis of the Export-led Growth Hypothesis: Evidence for BIMP-EAGA Countries," Philippine Journal of Development, 63 (XXXIV), 25-42.

Hill, H., B. Resosudarmo, and Y. Widyattama (2008), "Indonesian's Changing Economic Geography," CCAS Working Paper. No. 12, April 2008, Center for Contemporary Asian Studies, Doshisha University.

Jackson, J.C. (1970), "The Chinese in the West Borneo Goldjields: A Study in Cultural Geography," University of Hull Occasional Paper in Geography 15.

Majid, A.M., D.F. Anugerah, and I.N. Kurniati (2012), “Analysis of Sectoral Efficiency and Policy Responses to Sectoral Economy in Provincial Level," Bulletin of Monetary Economics and Banking, 14(3), 317-338. 
Mitsuhiro, H. (2005), "Structural Change in Indonesian Industry and Trade: An InputOutput Analysis," Developing Economies, XLIII(1), 39-71.

Province Office of West Kalimantan Plantation (2011), Plantation Data of West Kalimantan, Pontianak.

Setiadi, D., M. Lubis, and B. Sukongko (2006), “The Relationship between the Regional Government Policy and Termination of Employment of Timber Workers in West Kalimantan," Journal of Research and Development, 1(1), 20-36.

Timmer, M.P., and J.V. Gaaitzen (2008), "Structural Change and Growth Accelerations in Asia and Latin America: A New Sectoral Data Set," Cliometrica, 5, 8-29. 